\title{
Avrupa Birliği-Azerbaycan İlişkileri
}

\author{
Ali Samir MERDAN*
}

\begin{abstract}
$\ddot{O} Z$
Sovyetler Birliği'nin çökmesinden sonra iki kutuplu sistemde köklü değişiklikler meydana gelmiştir. Bu süreçte çok daha faal bir politikaya yönelen Avrupa Birliği, coğrafi konumuna ek olarak sahip olduğu petrol ve doğalgaz gibi enerji kaynaklarl sebebiyle Azerbaycan'la yeni ilişkiler oluşturmaya başlamıştır. Bu bağlamda Avrupa Birliği, Azerbaycan'a TACIS, EMPI ve ENI Programları çerçevesinde ekonomik yardımlarda bulunmuş, tarihî İpek Yolu'nu yeniden faal duruma getirme politikası ve enerji politikalarını devreye sokarak yardımlarını çeşitlendirmiştir. Avrupa Birliği'nin uyguladığ sonucunda her iki taraf arasında yakınlaşma yaşanmıştır. Yapılan Ortaklık ve Işsbirliği Anlaşması yürürlüğe girdikten sonra Avrupa Birliği ile Azerbaycan arasındaki bu yakınlaşmanın hukuki temelleri de atılmıştır. Yaşanan bu karşılıkl yakınlaşma, bazı sorunları da beraberinde getirmiştir. Avrupa Birliği'nin Merkezî ve Doğu Avrupa devletlerine doğru genişlemesi, beraberinde özellikle güvenlikle ilgili problemler de getirmiştir. Bu bağlamda Avrupa Birliği, Azerbaycan üzerinden gelen tehditlerin engellenmesi için bu devleti 2004'te Avrupa Komşuluk Politikasina ve 2009'da Doğu Ortaklı̆̆ Politikasına dâhil etmiştir. Bu çalışmanın amacı; TACIS, ENPI, ENI Programları ve tarihî İpek Yolu'nu yeniden faal duruma getirme politikası ile oluşturularak geliştirilen ekonomik ilişsileri; Ortaklık ve İşbirliği Anlaşması ile temelleri atılan hukuki ilişkileri; Avrupa Komşuluk ve Doğu Ortakllğ̆ Politikaları ile çerçevelenen siyasi ilişkileri değerlendirmektir.
\end{abstract}

Anahtar Kelimeler: Avrupa Birliği, Azerbaycan, Ortaklık ve İşbirliği Anlaşması, Avrupa Komşuluk Politikası, Doğu Ortaklığı Politikası.

Jel Sinıflandırmast: F50, F53, F59

\section{European Unıon-Azerbaijan Relations}

\begin{abstract}
After the collapse of the Soviet Union, radical changes have occurred in the bipolar system. In addition to its geographical position, the European Union has started to create new relations with Azerbaijan due to its energy resources such as oil and natural gas. In this context, the European Union has provided economic assistance to Azerbaijan within the framework of TACIS, EMPI and ENI Programs, and has diversified its aid by re-activating the historical Silk Road and energy policies. As a result of these policies implemented by the European Union and its financial assistance to Azerbaijan, there has been a rapprochement between the two sides. After the entry into force of the Partnership and Cooperation Agreement, the legal foundations of this rapprochement between the European Union and Azerbaijan were laid. This mutual rapprochement has brought with it some problems. The enlargement of the European Union towards the Central and Eastern European states has also brought about security problems. In this context, the European Union has included this state in the European Neighbourhood Policy in 2004 and Eastern Partnership Policy in 2009 in order to prevent the threats emanating from Azerbaijan. The aim of this study is to evaluate the economic relations developed by TACIS, ENPI, ENI Programs and the historical Silk Road, and to evaluate the legal relations that are based on the Partnership and Cooperation Agreement, and the political relations that are framed by the policies of European Neighbourhood and Eastern Partnership.
\end{abstract}

\footnotetext{
* Dr. Öğretim Üyesi, Çankırı Karatekin Üniversitesi, İktisadi ve İdari Bilimler Fakültesi, Uluslararası İlişkiler Bölümü, alisamirmerdan@gmail.com
} 
Keywords: European Union, Azerbaijan, Partnership and Cooperation Agreement, European Neighborhood Policy, Eastern Partnership Policy.

Jel Classification: F50, F53, F59

\section{GíRIŞ}

İkinci Dünya Savaşı sonrasında Avrupa'nın bir kere daha bu tür bir çatışmaya sahne olmaması için bütünleşmiş bir Avrupa oluşturmaya yönelik girişimler, 1950'lerden itibaren kalıcı meyvelerini vermeye başladı. Hem ekonomik kalkınmayı hem de Sovyetler Birliği'ne (SB) karşı birlikteliği amaçlayan Batı Avrupa devletleri, Ruhr bölgesindeki zengin kömür yatakları ve çelik tesislerinin işletilmesi için uluslararası bir örgüt kurdular. Böylece, Batı Avrupa devletlerinden Fransa, Almanya, İtalya ve Benelux devletleri arasında imzalanan 18 Nisan 1951'deki Paris Antlaşması ile Avrupa Kömür ve Çelik Topluluğu (AKÇT) oluşturuldu. Bu birliktelik daha sonra ekonominin tüm sektörlerini kapsayacak şekilde genişletilerek Avrupa Ekonomik Topluluğu (AET) ve Avrupa Atom Enerji Topluluğu (AAET) kuruldu (Arat, Erhan, 2001: 808-811).

Yaşanan süreçte, 1950'lerin sonlarına gelindiğinde, Batı Avrupa devletleri tarafindan ekonomi alanında AKÇT, AAET ve AET oluşturuldu. 1960'larda ise Füzyon Antlaşması'yla bütünleşme süreci devam etti ve üç örgüte birden Avrupa Toplulukları (AT) adı verildi (Sander, 1998: 311-315).

1970'lerin belirgin bir özelliği, AT’nin duraksamalar yaşamasıydı. 1968'de gümrük duvarlarının kaldırılması ve ortak pazarın işleyişi pratikte etkin oldu. Buna karşın; kurumsal yapıdaki işleyişin hantal olması ve vetonun önemli bir silah olması bu başarıları geri planda bıraktı. Büyük bunalımlarla sarsılan AT, Tek Senet'e kadar duraksama dönemi yaşadı (Pescatore, 1987: 9-18).

1987'de yürürlüğe giren Tek Senet ile birlikte duraksama dönemini geride bırakan AT, ekonomik alanda iç pazar hedefine ulaştığı gibi kurumsal işleyişindeki tıkanıklı̆ğ da ortadan kaldırmayı başardı. Bütünleşme yolunda önemli bir adım atan AT, bütünleşmenin derinleşme aşamasında kurumsal yapısındaki ve işleyişindeki aksaklıkları gidermeye başlarken (Baykal, 2003: 10), genişleme aşamasında ise Merkezî ve Doğu Avrupa devletleriyle yakınlaşma yolunda önemli gelişmeler kaydetti.

SB'de, 1985 'te iktidara gelen Mihail Gorbaçov'un diş politika olarak seçtiği Batı ile yakınlaşma politikası ve iç politika olarak seçtiği "perestroyka" (ekonominin yeniden yapılanması) ile "glasnost" (siyasi açıklık) uygulamaları, ekonomik ve siyasi hayatta beklenen etkiyi sağlayamayınca SB'nin dağılacağı anlaşıldı. AT, dağılma aşamasında olan SB'yle ilişkilere önem vererek 18 Aralık 1989'da Ticaret ve İşbirliği Anlaşması'nı imzaladı (Hasanov, 1998: 194-198). Anlaşmanın amacı; ticari ve ekonomik işbirliği konularında SB ile AT arasında bağlantının kurulmasıydı.

Soğuk Savaş'ın sona ermesiyle birlikte coğrafi yakınlık ve paylaşılan ortak değerler gibi nedenlerle AT, öncelikle Merkezî ve Doğu Avrupa devletlerine önem verdi. Bununla birlikte AT, SB'nin dağılmasıyla bağımsızlığını ilan eden Azerbaycan'1 da göz ardı etmedi. Bu bağlamda Azerbaycan'ın bağımsızığını kazanması, jeopolitik açıdan Azerbaycan'a verilen önemi daha da artırdı. Bağımsızlığını ilan eden Azerbaycan'la hemen diplomatik ilişkiler kuran AT, Azerbaycan'da uygulanmaya başlanan yenileşme hareketlerini yakından destekledi. Demokrasinin yerleşmesini ve 
serbest piyasa ekonomisine geçiş hareketlerini destekleyen AT, Azerbaycan'a önemli ölçüde teknik ve ekonomik yardım sağladı. Bu bağlamda AT, 1991'den itibaren Technical Asistance to Commonwealth of Independent States (TACIS) Programı'n1 uygulamaya başladı (Avrupa Komisyonu, 1998, 3 Temmuz: 57). Programın esas amacı siyasi bağımsızlık ve ekonomik kalkınma yolundaki Azerbaycan'ın çabalarını desteklemekti. 2007'den itibaren de European Neighbourhood and Partnership Instrument (ENPI) Programı uygulanmaya başlandı. ENPI Programı, Avrupa Komşuluk Politikasının hayata geçirilmesi için temel finansal araçtı (http://www.ENPI-info.eu/library/content/azerbaijan-national-indicative-programme2011-2013, ET: 02.03.2018). 2014'ten itibaren ise European Neighbourhood Instrument (ENI) Programı uygulanmaya konulmuştur. 2014-2020 dönemini kapsayan ENI Programı, Doğu Ortaklığı Politikası'nın hedeflerine ulaşmasını desteklemek amaciyla oluşturulmuştur (http://www.ENPI-info.eu/main.php?id= 402\&id_type=2\&lang_id=450, ET: 12.03.2018).

Maastricht Antlaşması ile Avrupa bütünleşmesinin temelini oluşturan AB, Azerbaycan'la ilişkilerin hukuki zeminde geliştirilmesi amacıyla da Ortaklık ve İşbirliği Anlaşması'nı imzaladı. Azerbaycan'ın demokrasi, insan hakları ve piyasa ekonomisini ihlal edilecek davranışlarına karşı AB'ye müeyyide uygulama hakkı veren bu anlaşma önemlidir. Anlaşma on yıl sürelidir ve kendiliğinden birer y1l uzayabilmektedir (Töre, 1996: 17). 2017'den itibaren AB ile Azerbaycan, Ortaklık ve İşbirliği Anlaşması'nın güncellenmesi için müzakerelere başlamıştır (http://www.avrupa.info.tr/tr/news/ab-azerbaycan-iliskileri-8942, ET: 15.03.2018).

AB'nin Azerbaycan'a yönelik politikası açısından 1995 yılı önemli bir dönüm noktasıdır. $1995^{\prime}$ te $\mathrm{AB}$, Ortak Dış ve Güvenlik Politikası altında Azerbaycan'a yönelik siyasi bir program oluşturdu. Artık AB üyesi devletlerin Azerbaycan'la kurduğu ikili ilişkiler bu program çerçevesinde AB'nin bölgeye yönelik dış politikası dâhilinde olacaktı. AB'nin aldığı "ortak karar", Azerbaycan ile ilgili jeopolitik ve ekonomik çıkarları olduğunun göstergesidir (Töre, 1996: 14).

Görüldügü gibi $\mathrm{AB}$; Azerbaycan'a piyasa ekonomisine geçiş aşamasında TACIS, ENPI ve ENI Programları çerçevesinde maddi ve teknik yardım sağlamakta; Azerbaycan'daki enerji kaynaklarıyla ilgilenmekte; Azerbaycan'la ticari ilişkilerini hızla geliştirmekte; Azerbaycan'1 Avrupa Komşuluk Politikası ve Doğu Ortaklığı Politikası'na dâhil ederek ikili ilişkileri daha üst düzeye çıkarmaktadır.

$\mathrm{Bu}$ çalışmanın amacı, AB-Azerbaycan ilişkilerini incelemektir. Ekonomik ve siyasi ilişkilerin dayanağı dikkate alındığında, ilişkilerin çerçevesini çizen temel hukuki metin olan Ortaklık ve İşbirliği Anlaşması'nın incelenmesi, siyasi ve ekonomik ilişkilerin anlaşılmasına yardımcı olacaktır. Ayrıca AB'nin Azerbaycan'a yönelik politikasını saptamak açısından TACIS, ENPI, ENI ve özellikle tarihî İpek Yolu'nun yeniden canlandırılmas1 düşüncesiyle 1993'te başlatılan Transport Corridor Europe-Caucasus-Asia (TRACECA) ile petrol ve doğalgaz boru hatlarının geliştirilmesi, işletilmesi ve güvenliğinin sağlanmasını amaçlayan Interstate Oil and Gas Transport to Europe (INOGATE) Programları'nın bir bütün olarak değerlendirilmesi de gerekecektir. Son olarak da Azerbaycan'ın AB'ye yakınlaşma 
sürecine nasıl girdiği, Azerbaycan'ın AB için önemi ve AB’nin Avrupa Komşuluk Politikası ile Doğu Ortaklığı Politikası'nın olası sonuçları değerlendirilecektir.

\section{AB-AZERBAYCAN İLIŞKILERININ HUKUKİ ALT YAPISI}

\section{A. Azerbaycan'la İmzalanan Ortaklık ve İşbirliği Anlaşması}

AB ve Azerbaycan arasındaki Ortaklık ve İşbirliği Anlaşması, 1996 yılının Nisan ayında imzalandı ve 1999 yılının Temmuz ayında yürürlüğe kondu. Böylece AB ile Azerbaycan arasındaki ilişkilerin ticari ve ekonomik kapsamının genişletilmesi yönünde ilk adım atılmış oldu (http://eur-lex.europa.eu/legalcontent/EN/ALL/?uri=CELEX:21999A0917\%2801\%29, ET: 12.03.2018). Ortakl1k ve İşbirliği Anlaşması'nın imzalandığı ve yürürlüğe girdiği tarihler arasında geçerli olmak üzere de Geçici Anlaşma yapıldı. Geçici Anlaşma, Ortaklık ve İşbirliği Anlaşması'nın yürürlüğe girmesinden önce ticari hazırlıklar (Tarife hazırlıkları, miktar kısıtlamalarının kaldırılması vb.) yapılmasına ve önlemler (Koruma durumu, anti-damping kuralları vb.) alınmasına imkân vermekteydi. 1999 yılının Temmuz ayında uygulanmaya konulan Ortaklık ve İşbirliği Anlaşması, ticaretle ilgili konuları kapsayan Geçici Anlaşma’nın yerini aldı.

AB ile Azerbaycan arasında imzalanan bu anlaşma demokratik değerler, insan hakları, kültürel konular, suç ve suçlularla mücadele, çevresel sorunlar, teknolojik gelişmeler ve telekomünikasyon; ticari, ulaşım ve gümrükle ilgili meselelerle petrol ve doğalgaz gibi enerjiyle ilgili konuları kapsamakta ve karşılıklı işbirliği öngörmektedir. Bununla birlikte aynı anlaşmayla devlet ve hükümet başkanları, bakan ve milletvekilleri düzeyinde $\mathrm{AB}$ ve Azerbaycan arasındaki siyasi diyalog da kurumsallaşmaktadır.

Ortaklık ve İşbirliği Anlaşması, Azerbaycan'ın AB'ye katılımı için destek sunmaktadır. Böylece AB ve Azerbaycan halkları arasında daha yakın bir ilişki kurulacak ve iş adamlarıyla yatırımcılara daha istikrarlı bir ortam sağlanacaktır. Ortaklık ve İşbirliği Anlaşması'nın yürürlüğe girmesi Soğuk Savaş Dönemi’nin de sona erdiğini göstermektedir. Aynı zamanda, demokratik ve ekonomik reform sürecinde Azerbaycan tarafından bir atılım yapılmış olduğunun AB tarafından kabul edildiğini de göstermektedir.

Ortaklık ve İşbirliği Anlaşması, iş dünyası için pek çok kazanç sağlamıştır: Azerbaycan'da kurulan AB şirketleri için en çok kayrılan ülke kuralı uygulanmıştır; AB'den yapılan ithalatta miktar kısıtlamaları önemli oranda azaltılmıştır; finansal hizmetler alanında kurumlaşma aşamaları kolaylaştırılmıştır; Azerbaycan'daki hizmet piyasasına katılımın artması sağlanmıştır.

AB, Azerbaycan'ın Dünya Ticaret Örgütü'ne (DTÖ) katılımını, reform sürecinin hızlandırılması ve ortak pazara katılımının sağlanması için çok önemli bir hedef olarak görmüştür. AB, Azerbaycan'ın DTÖ’ye katılımını kolaylaştırmak için teknik yardım sağlamıştır. Bu husus, AB ve Azerbaycan arasında özellikle standartlar, sertifikasyon ve fikrî mülkiyet hakları ile ilgili konularda birtakım önemli problemlerin çözümüne katkıda bulunmuştur. Bu durum; TACIS, ENPI, ENI Programları ve Ortaklık ve İşbirliği Anlaşması ile Azerbaycan’a bulunulan taahhütlerin daha iyi yerine getirilmesine olanak sağlamıştır. 
Ortaklık ve İşbirliği Anlaşması'ndan sonra karşılıklı anlaşmalar imzalanmış ve Azerbaycan'a Avrupa Komşuluk Politikası ile Doğu Ortaklı̆̆ Politikası uygulanmıştır. $\mathrm{AB}$ ile Azerbaycan arasında imzalanan temel hukuki belgeler şunlardır: 14 Kasım 2006'da imzalanan AB-Azerbaycan Komşuluk Politikası Eylem Planı; 7 Mayıs 2009'da imzalanan Doğu Ortaklığı Beyannamesi ve 22 Mayıs 2015'te imzalanan Doğu Ortaklığ1 Deklarasyonu (http://economy.gov.az/index.php?option= com_content\&view=article\&id=1038\&Itemid=183\&lang=az, ET: 16.03.2018). AB ile Azerbaycan arasında imzalanan bu hukuki belgeler, Ortaklık ve İşbirliği Anlaşması'nın tamamlayıcısı niteliğindedir. Ayrıca bu belgeler, AB ile Azerbaycan arasındaki işbirliğinin gelişmesine önemli katkıda bulunmuştur.

Temmuz 2016'da da Doğu Ortaklığı Programı'na dâhil edilen Azerbaycan ile $\mathrm{AB}$ arasında bir protokol imzalanmıştır. Bu protokol, Azerbaycan'ın $\mathrm{AB}$ program ve kurumlarına katılımını öngörmektedir. 14 Kasım 2016'da ise AB Konseyi, Yüksek Temsilci'ye $\mathrm{AB}$ ve üyesi devletler adına Azerbaycan'la kapsamlı bir anlaşmayı müzakere etme yetkisi vermiştir. Yeni anlaşmaya ilişkin müzakereler, Cumhurbaşkanı İlham Aliyev'in Brüksel'e yaptığı ziyaretin ardından 7 Şubat 2017'de başlatılmıştır (https://www.avrupa.info.tr/tr/news/ab-azerbaycan-iliskileri-4431, ET: 16.03.2018). Bu yeni anlaşmayla 1999 'da yürürlüğe giren Ortaklık ve İşbirliği Anlaşması güncellenerek mevcut siyasi diyalog için yeni bir temel sunulması ve karşılıklı fayda sağlayan bir işbirliğine imkân verilmesi amaçlanmıştır.

\section{B. Ortaklık ve İşbirliği Anlaşması ile Oluşturulan Ortaklık Kurumları}

Ortaklık ve İşbirliği Anlaşması'nın XI. başlığında kurumsal hükümler, genel hükümler ve sonuç hükümleri düzenlenmiştir. Anlaşmanın 81. ve 88 . maddeleri arasında yer alan bölümün kurumsal hükümler yer almış olup ortaklık organlarının yapısı ve işleyişi düzenlenmiştir. Bu organlar, İşbirliği Konseyi, İşbirliği Komitesi ve Parlamenter İşbirliği Komitesi'dir (http://eur-lex.europa.eu/ legal-content/EN/ALL/?uri=CELEX:21999A0917\%2801\%29, ET: 12.03.2018).

\section{1. İşbirliği Konseyi}

$\mathrm{Bu}$ konseyin görevi yapılan anlaşmanın uygulanmasını sağlayarak anlaşma çerçevesinde ortaya çıkan başlıca meselelerle $A B$ ve Azerbaycan'ın karşlıklı menfaatlerinden kaynaklanan uluslararası konuları irdelemektir. Bununla birlikte İşbirliği Konseyi, iki tarafın mutabakatı ile taraflara çeşitli tavsiyelerde de bulunabilmektedir.

Bakanlar düzeyinde olmak üzere en az yılda bir kez toplanan İşbirliği Konseyi, AB Konseyi üyeleriyle Azerbaycanlı bakanlardan oluşmaktadır. Konseye sirayla $\mathrm{AB}$ 'nin bir temsilcisi ve Azerbaycan hükümetinden bir temsilci başkanlık yapmaktadır.

Görev ve sorumluluklarını yerine getirirken kendisine yardım edebilmesi için özel komite ya da organlar kurulması kararı İşbirliği Konseyi'nin tasarrufundadır. $\mathrm{Bu}$ tasarrufuyla konsey, oluşturduğu komite ya da organların teşekkülü, yetkileri ve çalışma yöntemlerini belirleyebilmektedir.

Taraflardan biri Ortaklık ve İşbirliği Anlaşması'nı uygulamada ya da yorumlamada ortaya çıkabilecek uyuşmazlıkların çözümlenmesi için bu konseye başvurabilir. Konsey uyuşmazlığı çözmek için tavsiyelerde bulunabilir. Bununla 
birlikte konseyin ortaya çıkan uyuşmazlıkların çözümlenmesi için çeşitli kurallar koyma yetkisi vardır. Ortaya çıkan uyuşmazlıkların konsey içinde giderilemediği durumlarda ise taraflar ve konseyce arabulucular tayin edilir. Arabulucuların aldıkları karar taraflar adına tavsiye niteliğinde olup bağlayıcı özellik taşımamaktadır.

\section{2. İșbirliği Komitesi}

İşbirliği Komitesi, AB Komisyonu ve Azerbaycan'ın kıdemli kamu görevlileri düzeyindeki temsilcilerinden oluşmaktadır. İşbirliği Komitesi’ne sırayla $A B$ ve Azerbaycan'ın temsilcileri başkanlık yapmaktadır.

Bu komite, İşbirliği Konseyi'nin görev ve sorumluluklarını yerine getirmesi için kurulmuştur. Konsey, en az yılda bir kez gerçekleşen kendi toplantılarının hazırlık çalışmaları da dâhil olmak üzere komitenin görev ve sorumluluklarını belirleyerek sınırlandırabilmektedir. Gerekli durumlarda İşbirliği Konseyi kimi yetkilerini komiteye devredebilmektedir.

\section{Parlamenter İşbirliği Komitesi}

Parlamenter İşbirliği Komitesi, Azerbaycan Millî Meclis üyeleri ile AB Parlamentosu üyelerinin toplanıp görüş alışverişinde bulundukları bir forumdur. Komite, belirledikleri kurallar çerçevesinde istedikleri zamanda toplanır. Komite'ye sırayla AB Parlamentosu üyeleri ve Azerbaycan'ın milletvekilleri başkanlık yapmaktadır.

$\mathrm{Bu}$ komitenin; konseyden yapılan anlaşmanın nasıl uygulandığına dair bilgi edinme, konseyin yaptığı çalışmalardan haberdar olma hakkı vardır. Bununla birlikte konseye tavsiyelerde bulunma yetkisine de sahiptir.

\section{AB-AZERBAYCAN ARASINDAKİ EKONOMIK ILIŞKILER}

$\mathrm{AB}$, Azerbaycan'la ilişkilerini başlangıçta teknik yardımlar şeklinde sürdürmüş ve Ortaklık ve İşbirliği Anlaşması'nın imzalanmasıyla birlikte hukuksal çerçeveye oturtmuştur. İlişkilerin bu şekilde başlamasının nedeni, o dönemde AB'nin dış politikadan yoksun olmasıdır. Yine de AB, Azerbaycan politikasına Amerika Birleşik Devletleri (ABD) ve Rusya Federasyonu (RF) kadar aktif bir şekilde katılmasa bile bağımsızlığının güçlendirilmesi, demokratik değerler, insan hak ve özgürlükleri ve hukukun üstünlügünü benimseyen devlet yapısının oluşturulması amacıyla yardımda bulunarak dolaylı bir şekilde katılmıştır.

1991'de AB'nin bağımsızlıklarını yeni kazanan devletlere yönelik başlattığ TACIS Programı sayesinde, 2006'ya gelindiğinde Azerbaycan'a yaklaşık 410 milyon Avro tutarında insani, teknik ve gıda yardımı sağlandı. AB'nin sağladığı bu ödenekle Azerbaycan'daki altyapıyla ilgili sorunların giderilmesi, siyaseten yenileşme, özel sektör ve insan kaynaklarının geliştirilmesi, kamu sektöründe gümrük ve vergi sisteminin modernizasyonu, demokrasi ve insan hakları alanında reformların gerçekleştirilmesi ve sosyal refahın iyileştirilmesi sağlandı (http://ec. europa.eu/external_relations/ceeca/tacis/index.htm, ET: 05.01.2018).

2007'den itibaren TACIS Programı, ENPI Programı ile ikame edildi. Daha geniş kapsam ve yetkiye sahip olan ENPI Programı, Avrupa Komşuluk Politikası'nın hayata geçirilmesi için temel finansal araçtı. ENPI Programı'nın üç temel stratejik amacı vardı. Bunlar; demokrasi ile insan haklarının uygulanmasını, piyasa ekonomisinin benimsenmesini ve ikili işbirliğinin geliştirilmesini sağlamaktı. 2007'de 
yürürlüğe giren ENPI Programı, 2013'e gelindiğinde Azerbaycan'a yaklaşık 215 milyon Avro tutarında yardım sağladı (http://eeas.europa.eu/archives/docs/enp/ pdf/pdf/country/enpi_nip_azerbaijan_en.pdf, ET: 17.03.2018).

ENPI Programı, 2014'ten itibaren AB-Azerbaycan ilişkilerinin daha da geliştirilmesi için ENI Programı'na dönüşmüştür. ENI Programı, Doğu Ortaklığı Politikası'nın hayata geçirilmesi için temel finansal araçtır. Böylece ENI Programı, Azerbaycan'1 AB'ye daha da yakınlaştırmayı hedeflemiştir. 2014-2020 dönemini kapsayan ENI Programıyla Azerbaycan'a yaklaşık 170 milyon Avro tutarında yardım yapılması öngörülmüştür (http://eeas.europa.eu/archives/docs/enp/pdf/financing-theenp/azerbaijan_2014_2017_programming_document_en.pdf, ET: 13.03.2018).

$\mathrm{Bu}$ yardımlar dışında AB, Azerbaycan'a yönelik Trans European Mobility Programme for University Studies (TEMPUS) Programı, Gıda Güvenliği Programı, Çatışma Bölgelerinin Rehabilitasyonu Programı, Müstesna Mali Yardım Programı gibi çeşitli yardım programlarını da sürdürmüştür.

$\mathrm{AB}, \mathrm{RF}$ 'nin ulaştırma ağları üzerindeki tekelini kırmak ve İpek Yolu'nu yeniden canlandırmak düşüncesiyle Azerbaycan'dan geçecek yeni koridorlar oluşturmaya çalışmıştır. $\mathrm{Bu}$ amaçla geliştirilen programlardan en önemlisi TRACECA Programı'dır. Siyasi olarak ABD'nin desteklediği ve ekonomik olarak da AB'nin yükümlülüğünü üstlendiği TRACECA Programı, RF'nin güneyinden geçen bir ulaşım güzergâhı oluşturmayı amaçlamıştır (Demir, 2003: 369-372). Bu program çerçevesinde RF ve İran'ın Azerbaycan üzerindeki etkisini sınırlamak amacıyla kara, deniz ve demir yolları ile Azerbaycan'ın Avrupa'ya bağlanması hedeflenmiştir.

Uluslararası arenada petrol ve doğalgaz gibi enerji kaynaklarının her geçen gün çok daha önemli hâle gelmesi, Orta Doğu petrolüne olan bağımlılık ve mevcut kaynakların hızla azalması $\mathrm{AB}$ devletlerini yeni çözümlere yöneltmiştir. $\mathrm{Bu}$ nedenlerden dolayı $\mathrm{AB}$ devletleri ilgilerini Azerbaycan'nn petrol ve doğalgaz kaynaklarına çevirmişlerdir. Enerji kaynaklarının çeşitlendirilmesi amacıyla AB devletleri tarafindan INOGATE Programı geliştirilmiştir. $\mathrm{Bu}$ programın hedefi, Azerbaycan'daki mevcut boru hatlarının iyileştirilmesi ve modernizasyonu ile yeni stratejik güzergâhlarının oluşturulmasıdır (http://www.inogate.org/, ET: 18.01.2018). Ayrıca bu program, Azerbaycan'a sağlamakta olduğu ekonomik ve siyasi avantajlar açısından da önem taşımaktadır.

Azerbaycan'ın, Devlet İstatistik Enstitüsü'nden alınan verilere göre dış ticaretinde en büyük paya $\mathrm{AB}$ devletlerinin sahip olduğu görülmektedir. $\mathrm{AB}$ ile Azerbaycan arasındaki sıkı ilişkiler, ikili arasındaki ticari ilişkileri de olumlu yönde etkilemiştir. Özellikle Azerbaycan ile İngiltere arasındaki yakınlık, Azerbaycan'ın dış ticaretinde en büyük paya $A B$ ve $A B$ üyesi devletlerin sahip olmasını sağlamıştır.

1994 yılında imzalanarak yürürlüğe giren Asrın Anlaşması'ndan sonra İngiltere'nin British Petrol adlı şirketinin öncü olmasıly Azerbaycan'da İngiliz şirketlerinin sayısı da artmıştır. Azerbaycan'da son zamanlarda yüzden fazla İngiliz şirketi faaliyet göstermektedir. Buna karşın İngiltere, Azerbaycan'ın 2017'deki başlıca ticari ortakları sıralamasında üçüncü sırada yer almaktadır. Bunun nedeni, İngiltere ile ticari ilişkilere sadece petrol ve doğalgaz ürünlerinin konu olmasıdır. Azerbaycan'ın 2004'teki ticari ortakları siralamasında birinci sırada İtalya, 
dördüncü sırada Türkiye yer almaktadır. Bunun nedeni, bu devletlerle ticari ilişkilerde petrol ve doğalgaz ürünlerinin yanı sıra gıda, pamuk, kimyasallar, havyar, makine ve donanımların da yer almasıdır. Azerbaycan'ın 2017'deki beş ticari ortağından ikisinin AB üyesi devlet ve birinin de aday devlet olması, 2017'de dış ticaret haddi bakımından Avrupa kıtasının birinci sırada yer almasını sağlamıştır (https://www.stat.gov.az/, ET: 17.03.2018).

\section{AB-AZERBAYCAN SIYYASİ İLIŞKIILERİ}

A. AB İçin Azerbaycan'ın Önemi

SB'nin dağılması Kafkasya'da otorite boşluğuna sebep olmuştur. $\mathrm{Bu}$ bağlamda Kafkasya'nın jeopolitik konumu küresel ve bölgesel güçlerin ilgisini genel olarak bu bölgeye ve özel olarak da Azerbaycan'a yönlendirmiştir. RF'nin Azerbaycan'1 arka bahçe olarak değerlendirmesinin yanında ABD'nin de Azerbaycan'da etkin olmayı hedeflemesi, bu devletin uluslararası rekabetin odağı hâline gelmesi sonucunu doğurmuştur. Aralarındaki tarihî ve kültürel bağlar sebebiyle Türkiye ve İran da Azerbaycan siyasetinde etkili olan diğer önemli güçlerdendir. Dünya siyaseti içindeki etkinliğini artırmaya çalışan AB'nin de Azerbaycan denkleminde daha aktif bir politika izleyeceği öngörülebilir.

AB, Azerbaycan'ın bağımsızlığını kazanmasının hemen ardından ikili iliş̧kileri başlatmıştır. $\mathrm{Bu}$ bağlamda 1991 yılının sonunda Azerbaycan'ın bağımsızlığını resmen tanıyarak 1992 yılının başlarında bu devletle diplomatik ilişkileri kurmuştu (Demir, 2003: 369-372).

$\mathrm{AB}, \mathrm{SB}$ 'nin dağılmasından sonraki ilk yıllarda Azerbaycan'ın yaşadığı çatışmanın, kendisini etkilemesinin önüne geçebilmek için RF'nin bu devletle ilgili aktif politikasını destekleyen bir tavır sergilemişti. AB'nin, Azerbaycan ilişkilerine yönelik yaklaşımının belirlenmesinde ilk önemli adım, AB Komisyonu tarafından Azerbaycan stratejisinin 1995 yılının Aralık ayında açıklanmasıyla atılmıştır (Demir, 2003: 365-366). Açıklanan bu stratejiye göre AB, Azerbaycan ile Ortaklık ve İşbirliği Anlaşması imzalanmasını öngörmüştü. Bu stratejiye göre AB'nin Azerbaycan'a olan ilgisi; jeopolitik, ekonomik ve güvenlik çerçevesinde belirlenen üç boyutla değerlendirilebilir.

\section{Jeopolitik Önemi}

AB'nin Azerbaycan'a olan ilgisi, dünyadaki şartların değişmesiyle birlikte Azerbaycan'ın da jeopolitik konumunun öneminin artmasından dolay1 yoğunlaşmıştır. RF, İran ve Türkiye ile Orta Asya'nın çerçevelediği, ayrıca Hazar Denizi'ne de kıyısı olan Azerbaycan stratejik açıdan önemli bir konumda bulunmaktadır. McKinder'ın ileri sürdüğü "Hearthland" teorisinde belirtildiği üzere dünyanın kalbi sayılan bu bölgenin hâkimi olanlar dünyayı yönetmede de söz sahibi olacaktır (Lorot, Thual, 2001: 55). Genel olarak Kafkasya ve özel olarak da Azerbaycan, bu teoriyle dikkat çekilen bölgelerden biridir.

Avrupa'nın doğu sınırında bulunan Azerbaycan'ın AB'ye üye olmasıyla ilgili gelişmeler yaşanmasa da gelecekte Azerbaycan, AB'ye bir çeşit sınır komşusu olabilecektir. Bu bağlamda $\mathrm{AB}$ ile Azerbaycan arasındaki ikili ilişkilerin geliştirilmesinin jeopolitik açıdan da zorunlu bir durum olduğunu söylemek mümkündür. 


\section{Ekonomik Açıdan Önemi}

AB'nin önem verdiği konuların başında serbest piyasa ekonomisi gelmektedir. Zira AB'nin kuruluş amaçlarından biri de ekonomideki sınırları kaldırarak pazarda bütünleşmeyi sağlamaktı. $\mathrm{Bu}$ bağlamda $\mathrm{AB}$, Azerbaycan ile ekonomik ilişkiler kurarken bu devletin ekonomisinin de liberalleşmesine önem vermiştir.

Dünya piyasaları için petrol ve doğalgaz gibi enerji kaynaklarının her geçen gün daha önemli hâle gelmesi ve enerji rezervlerinin de sınırlı olması AB'yi yeni arayışlara yönlendirmiştir. İhtiyaç duyduğu enerji konusunda Orta Doğu'ya olan bağımlılığını azaltmayı amaçlayan $\mathrm{AB}$ devletleri yönlerini Azerbaycan'ın sahip olduğu kaynaklara çevirmişlerdir. Azerbaycan $\mathrm{AB}$ için hem sahip olduğu enerji kaynaklarından dolayı hem de Hazar Havzası'nda bulunan rezervlerin Avrupa'ya taşınması için köprü vazifesi görmesinden dolayı önem arz etmektedir (Demir, 2003: 380).

\section{Güvenlik Açısından Önemi}

AB'nin kuruluş amacı öncelikle Avrupa devletleri arasında bulunan çeşitli sorunları gidererek istikrar ve güven ortamı sağlamaktı. Kendi aralarındaki tarihî problemleri önemli düzeyde gidermeyi başaran $\mathrm{AB}$ üyesi devletlerin, sistemlerine yönelen dış tehditlere karşı duyarlılıkları da artmıştır. AB'yi başlangıçta komünizm tehdidi bir araya getirmesine rağmen 1991'de SB'nin dağılmasından sonra üye devletlerin tehdit algılamalarında çeşitlenmeler olmuştur. Üye devletler arasında geliştirilen istikrar ve refahın korunmasını amaç edinen $\mathrm{AB}$, çeşitlenen tehditlere karşı yeni politikalar oluşturmuştur. (Lobjakas, 2014). Bu bağlamda oluşturulan Avrupa Komşuluk Politikası ve Doğu Ortaklığı Politikası ile hem yeni tehditlere karşı tedbir alınırken hem de sahip olunan değerlerin komşulara ihraç edilmesi stratejisi uygulanmıştır.

$\mathrm{AB}$, bir devletle ilişki kurarken sahip olduğu insan hak ve özgürlükleri, demokratik değerler, hukukun üstünlüğ̈̈, serbest piyasa ekonomisi gibi ilkelerini kabul etme şartı koyarak bir anlamda seçici davranmaktadır. AB'nin sahip olduğu bu değerleri komşularına ihracındaki temel amacı, onlarda da istikrar ortamı oluşmasını sağlayarak kendisi için tehdit unsuru olmalarının önüne geçmektir. Bu bağlamda Dağlık Karabağ sorunu nedeniyle Azerbaycan ile Ermenistan arasında yaşanan çatışmayı temel değerlerine yönelik bir tehdit olarak algılamakta ve sorunun barışçıl yollarla çözümlenmesi için diyalog geliştirmeye çalışmaktadır (Özen, 2004: 8-9).

\section{B. AB-Azerbaycan Arasındaki Yakınlaşma Süreci}

$\mathrm{AB}$ ile Azerbaycan arasındaki yakınlaşma, AB'nin doğuya genişleme stratejisi ve Azerbaycan'ın AB'ye yakınlaşması çerçevesinde gerçekleşmektedir.

\section{AB'nin Doğuya Genişleme Stratejisi}

$\mathrm{AB}, \mathrm{SB}$ dağıldıktan sonra sınırlarını tarihinin en geniş kapsamına ulaştırma sürecine girmiştir. 1991'den önceki dönemde güneye doğru genişleme stratejisi uygulayan $\mathrm{AB}$, SB'nin dağılmasından sonra stratejisini doğu yönüne çevirmiştir. Böylece tüm kıta topraklarını $\mathrm{AB}$ çatısı altında birleştirmeyi hedeflemiştir. $\mathrm{Bu}$ bağlamda, Merkezî ve Doğu Avrupa devletlerinin 1 Mayıs 2004'te tam üyelikleriyle başlayan sürece, Bulgaristan, Romanya ve Hirvatistan'la devam edilmiştir. Genişlemiş AB; RF, Belarus, Moldova ve Ukrayna ile sınırdaş olmuştur. 
Karadeniz'e doğrudan ulaşma imkânına sahip olan AB, Azerbaycan'la ilişkilerini daha geniş boyutta geliştirme imkânını elde etmiştir. Bu bağlamda AB'nin, Azerbaycan'1 Avrupa Komşuluk Politikasına dâhil etmesi ve 2009'dan itibaren de Doğu Ortaklığı Politikasını uygulaması, ikili ilişkilerin geliştirilmesine verdiği önemi göstermektedir.

\section{Azerbaycan'ın AB'ye Yakınlaşması}

SB'nin dağılmasından sonra sistem de dağılmış, hızlı bir yeniden yapılanma başlamıştı. $\mathrm{Bu}$ dönemde, dünyanın siyasi terminolojisinde de önemli ölçüde değişimler olmuş; demokratik değerler, insan hak ve özgürlükleri, serbest pazar ekonomisi gibi kavramlar önem kazanmıştı. Böyle bir ortamda eski sistemden kalan sorunların çözmek, varlıklarını korumak ve gelişme göstermek isteyen Azerbaycan Batı dünyasına yakınlaşmak zorunda kalmıştı. Genel olarak Batı dünyası, özel olarak da Avrupa ile hızlı bir şekilde ilişki kurma ve geliştirme sürecine giren Azerbaycan, Avrupa kaynaklı oluşumlara kısa zamanda üye oldu (Hüseynova, 2016, 23 Ekim: 4).

Tarihten gelen birtakım tecrübeler ve en önemlisi de SB ile uzun süreli beraberlik, Azerbaycan'1 genel ifadeyle Avrupa, özel ifadeyle AB'ye yakınlaştırmıştır. Çünkü Azerbaycan'ın SB'de bulamadığı özgürlük, demokrasi ve insan haklarına saygı gibi bazı kavramlar AB'de mevcuttur (Fairbanks, 2003: 8).

\section{AB'nin Azerbaycan'daki Çıkarları}

1. AB Bakış Açısıyla

Soğuk Savaş bittikten sonra $A B$, küresel güçler içinde yeni bir konuma sahip olmuştur. Soğuk Savaş döneminde Batı Bloğu, siyasal, ekonomik ve askerî yönden bir bütün olarak değerlendirilirken alt birimlerinden olan $\mathrm{AB}$, iki Almanya'nın birleşmesiyle bu blok içinde özel bir yer kazanmış, Maastricht Antlaşması ile de başlı başına bir güç olmuştur. $\mathrm{Bu}$ bağlamda $\mathrm{AB}$, Batı dünyasındaki diğer alt birimlere de alternatif olma özelliği gösteren bir merkez olma niteliği elde etmiştir (Davutoğlu, t.y.: 491). Bu çerçevede $A B$ de yeni politikalar oluşturmaya başlamıştır.

AB'nin Azerbaycan'a yönelik politikası, 1995'te AB Ortak Dış ve Güvenlik Politikası adı altında bu devlete yönelik siyasi bir program ile oluşmuştu. Buna göre kimi $\mathrm{AB}$ üyesi devletlerin Azerbaycan'la kurdukları ilişkiler artık AB'nin Azerbaycan'a uygulayacağı dış politikaya dâhil edilecekti. Ortak Dış ve Güvenlik Politikası ile AB, Azerbaycan üzerinde önemli çıkarları bulunduğunu ortaya koydu (Marquina, 2000: 223-224). Bu çıkarlara bakıldığında ekonominin öncelikli olduğu görülmektedir. AB'nin Azerbaycan'a yönelik geliştirdiği dış politikasının önceliğini ekonomik boyut ve bunun da temelinde Azerbaycan'ın sahip olduğu petrol ve doğalgaz gibi enerji kaynakları oluşturmaktadır.

Azerbaycan, $A B$ için petrol ve doğalgaz bakımından önemli bir kaynağa sahip olmasının yanında Hazar Havzası, Orta Asya ve Basra Körfezi'ne geçişi sağlayan önemli bir güzergâh özelliği taşımaktadır. AB ile Azerbaycan ilişkilerinin geliştirilmesini savunan yetkin birimler, bundaki temel amaçlarının bu devlet içinde istikrar sağlandıktan sonra Hazar Havzası ve Orta Asya'daki petrol ve doğalgaz gibi kaynaklara ulaşabilmek ve bunları Avrupa'ya taşıyabilmek olduğunu defaaten belirtmişlerdir (Davutoğlu, 2001: 476). 
AB'nin Azerbaycan'a olan ilgisini sadece ekonomik sebeplere değil, güvenlikle ilgili endişelere de dayandırmak mümkündür. Zira Avrupa'yı tehdit eden güvenlikle ilgili çeşitli problemlerin zaman kaybedilmeden ve yaygınlaşmadan ortaya çıktığı yerde çözümlenmesi öncelikli olmuştur. Bu bağlamda AB'nin doğu sınırında bulunan Azerbaycan, Avrupa kıtasının güvenlik ortamı için çok büyük bir öneme sahiptir. Kıtanın güven ve istikrar ortamının devamı açısından Azerbaycan'ın, güvenlik çemberindeki en önemli halkalardan biri olduğu söylenebilir.

AB'nin Azerbaycan'da konumunu güçlendirmesinin bir başka amac1; Azerbaycan'da ABD, RF, ÇHC gibi küresel aktörlerin ve Türkiye, İran, Suudi Arabistan gibi bölgesel aktörlerin etkinliklerini artırmaları ya da artırmak istemeleridir. Bu da AB'yi geç kalmadan harekete geçmeye sevk etmektedir.

\section{AB Üyesi Devletlerin Bakış Açısıyla}

AB'nin üç lokomotif devleti ile üç Kafkas devleti arasında tarihten gelen çok açık olmayan bir yakınlık söz konusudur. İngiltere ile Azerbaycan, Almanya ile Gürcistan ve Fransa ile Ermenistan arasındaki yakınlık, bu devletlerin Kafkasya'da çıkarlarının oluşmasına neden olmuştur.

Azerbaycan'ın İngiltere ile yakın ilişkileri vardır. İngiltere ile ilişkilerin farklı boyuta taşıması, 1994 yılının Eylül ayında imzalanan Asrın Anlaşması'yla İngiliz şirketi olan British Petrol'ün öncülüğünde başlamıştır. Azerbaycan'da şu anda yüzden fazla İngiliz şirketi faaliyet göstermektedir. Ermenistan'ın Fransa ile ilişkilerinin farklı boyut taşımasının başlıca nedeni ise Fransa'daki etkin Ermeni diasporasının varlığıdır. Gürcistan'ın da Almanya ile yakın ilişkileri vardır. Bu ilişkiler tarihseldir ve özellikle 1918 'de Gürcistan Demokratik Cumhuriyeti'nin kurulmasında Almanya'nın önemli desteği olmuştur. Ayrıca, SB Dışişleri Bakanı olduğu dönemde Gürcü asıllı Eduard Şevardnadze'nin Doğu ve Batı Almanya'nın birleşmesi için üstlendiği rol aralarındaki sempatinin esas nedenlerindendir.

Alman tarihinde özel bir yeri olan Avrasya kavramının devreye girmesi, genelde Kafkasya bölgesini ve özelde Azerbaycan'ı doğrudan ilgilendiren sonuçlar doğurmuştur. AB'nin sahip olduğu yüksek üretim kapasitesi sebebiyle ihtiyacı olan hammadde ve enerji kaynaklarına ulaşma çabası Almanya'yı gerek AB üyesi olarak gerekse de ulusal politikasından dolayı hammadde ve enerji kaynaklarınca zengin olan bölgelere yöneltmiştir (Davutoğlu, 2001: 476). Bu açıdan genelde Kafkasya bölgesi ve özelde Azerbaycan, bir doğal kaynak havzası ve geçiş ülkesi olarak Almanya için büyük önem taşımıştır. Almanya Dışişleri eski Bakanı Klaus Kinkel, SB dağıldıktan sonra bağımsızlıklarını ilan eden Kafkasya ve Orta Asya devletlerine dost olmalarının Almanya için gelecekteki refahın anahtarı olduğunu belirtmişti. Kinkel bu bağlamda Almanya'nın gelecek yürüyüşü için Türkiye'yi lokomotif, Azerbaycan'1 yürüyüş güzergâhının giriş kapısı, Gürcistan'1 önemli bir köprü, Kırgızistan'ı ise güzergâhın son durağı olarak nitelendirmişti (Heqq, 1997: 7-8). Fakat Avrasya güç dengelerinin orta ve uzun vadede önemli risklerinin olması bu devleti daha temkinli olmaya yöneltmiştir. Bu bağlamda Almanya'nın AB çatısı altında özel bir Kafkasya ve Orta Asya stratejisi geliştirmesi ve ulusal politikasının bir parçası olarak açılım yapması, İngiltere ve Fransa gibi AB üyesi diğer devletleri 
ve bunun yanında ABD'yi de rahatsız edebilecek bazı sonuçlar doğuracaktır (Davutoğlu, 2001: 476).

\section{AB'nin Azerbaycan'a Yönelik Avrupa Komşuluk Ve Doğu Ortaklığı Politikaları}

\section{1. İlişkilerin Kurulması ve Gelişimi}

AB'nin Azerbaycan ile ilk ilişkileri, aslında 1989 yılında SB ile AT arasında imzalanmış olan Ticaret ve İşbirliği Anlaşması çerçevesinde başlamıştı. $\mathrm{Bu}$ anlaşma çerçevesinde AT, Azerbaycan'ı da kapsayan çeşitli ekonomik projeler geliştirerek 1990 yılının Aralık ayında Roma'da yapılan Zirve'de Azerbaycan'da da hayata geçirilebilecek ekonomik ve siyasi reformları desteklemişti. AT'nin vereceği bu desteğin teknik yardım programı kapsamında gerçekleştirilmesi karara bağlanmıştı. AT Konseyi'nin 1991'de çıkardığı tüzükle destek programı resmi olarak başlatılmış oldu. SB dağıldıktan sonra ise AT, Azerbaycan'ın egemenlik ve bağımsızlığını hemen tanıdı (Çernyavskiy, 1998: 11-13).

AT Konseyi'nin Dışişleri Bakanları seviyesinde 1991 yılının Aralık ayında gerçekleştirdiği toplantının sonucunda "SB'den Ayrılan ve Doğu Avrupa' daki Yeni Devletlerin Tanınma Prensipleri” başlıklı belgede Azerbaycan'ın da AT'nin temel değerleriyle birlikte SB ile AT'nin 1989'da imzaladığı Ticaret ve İşbirliği Anlaşması'nın uygulanmasını kabul etmeleri şartı ortaya kondu. Bu bağlamda Azerbaycan, AT'nin öne sürdüğü hassas şartları saygiyla karş1layarak uyum göstereceklerini resmî olarak bildirdi. (Çernyavskiy, 1998: 14).

1994 yılının Mart ayından itibaren AB Konseyi Azerbaycan ile daha yakından ilgilenerek kurulacak ilişkileri belli anlaşmalar çerçevesinde yürütebilmek amaciyla bu devlete yönelik yeni politikalar oluşturmaya başladı. Buna ek olarak Konsey, Dağlık Karabağ'da yapılan ateşkesten memnuniyet duyarak Azerbaycan ile yeni ilişkiler kurma görüşmelerini başlatmak için karar aldı. AB'nin bu somut girişimiyle hem Azerbaycan'ın gergin siyasi ortamının normalleşmesine hem de yeni oluşturduğu Azerbaycan politikasına katkı sağladı (Çernyavskiy, 1998: 15-17).

AB Komisyonu ile Azerbaycan arasında 1995 yilında bir dizi toplant1 düzenlendi. $\mathrm{Bu}$ toplantılarda $\mathrm{AB}$ Komisyonu, diğer Avrupa devletleriyle de imzalanmış olan Avrupa Enerji Şartı'na Azerbaycan'ın da taraf olması tavsiyesinde bulundu. 1995 yılının Haziran ayında Lüksemburg'da düzenlenen AB Konseyi'nin Dışişleri Bakanları toplantısında ise Azerbaycan ile ilgili olarak 'ortak tutum'u öngören taslak kabul edildi. Bu taslak ile AB'nin ortak ilkelerinden olan demokratik değerlerin benimsenmesi ve serbest pazar ekonomisine geçiş sürecinde Azerbaycan'a yardımcı olunması gerekliliği vurgulandı. Buna ek olarak Azerbaycan'da gerçekleştirilecek ekonomik reformlar desteklenerek insani yardımlarda bulunulacağı da açıklandı (Komissina, 2001). Bu bağlamda AB Komisyonu alınan kararların uygulanması için; komşu devletlerin birbirlerinin bağımsızlık, egemenlik ve toprak bütünlüğüne saygı duyması, çatışmaların barışçıl yollarla çözümlenmesi, demokratik kurumlar ile insan hak ve özgürlüklerine önem verilmesi, ekonomik boyutta reformlar gerçekleştirilmesi, taraflar arasında siyasi diyalog geliştirilmesi gibi bazı kıstaslar koydu (Demir, 2003: 366). 
Düzenlenen karma toplantılardaki çalışmalar sonucunda $\mathrm{AB}$ Komisyonu Konsey'e, bağımsızlıklarını yeni kazanan diğer bazı SB devletleriyle olduğu gibi Azerbaycan için de Ortaklık ve İşbirliği Anlaşması imzalanarak yürürlüğe konması tavsiyesinde bulundu. Bu tavsiyenin hayata geçirilmesi için de karma çalışma komisyonları oluşturuldu. Bu bağlamda ikili ilişkilerin hukuki temelleri atılarak gelecekte yapılacak işbirliği alanlarının doğru olarak saptanmasına katkı sağlanması hedeflendi.

Tavsiye edilen söz konusu anlaşma 1996 yılının Nisan ayında Lüksemburg'da imzalandı. Hemen ardından AB Parlamentosu'nda Azerbaycan ile geliştirilecek ilişkiler için özel bir komisyon kuruldu. Bu komisyonun başkanlığına ise Parlamento'ya bağlı olarak çalışan Dış İlişkiler, Güvenlik ve Savunma Komitesi'nin başkanlığını da yürüten A. Alavanos getirildi. 1997 yılının Mart ayında da AB Parlamentosu, imzalanan Ortaklık ve İşbirliği Anlaşmasını onayladı (İtar-Tass Haber Ajansı: 2018, 14 Mart).

1996 yılının Eylül ayında Dış İlişkiler, Güvenlik ve Savunma Komitesi'nde Azerbaycan'da temsilcilik açılmasını da içeren AB'nin Azerbaycan politikasıyla ilgili önergesi onaylandı. Hemen ardından AB Komisyonu "AB'nin Azerbaycan Stratejisi" ile ilgili öneriyi Parlamento'ya sundu. Bu önerinin sunulma amacı; Azerbaycan'ın bağımsızlığına destek vermek, AzerbaycanErmenistan çatışmasının barışçıl yollarla ortadan kaldırılması ve tarafların mutabakata varmalarını temin etmek, Azerbaycan'da demokrasi ile sivil toplum değerlerini ve ekonomik gelişmeyi sağlamak idi. Bu belgeyle AB, Azerbaycan'1 stratejik çıkarlarına dâhil etti (Komissina, 2001).

AB Komisyonu'nda 1999 yılının Haziran ayında Ortaklık ve İşbirliği Anlaşması bağlamında Azerbaycan ilişkileriyle ilgili bir rapor hazırlandı. Bu raporda Dağlık Karabağ ile ilgili sorun ikili ilişkiler çerçevesinde değerlendirilerek çözüm yolları arandı (Avrupa Komisyonu, 1999, 7 June: 8).

2001 yılının Şubat ayında Erivan'da gerçekleştirilen AB Bakanlar Troykası'nda AB'nin Azerbaycan'a ilgisi tekrar ortaya kondu. Bu görüşmelerle AB'nin Dağlık Karabağ ile ilgili sorunun barışçıl yollarla çözümlenmesi ve ardından bölgenin imar ve inşa edilmesine katkıda bulunma isteği vurgulandı (Dartan, Hatipoğlu, 2001: 88-90).

AB Parlamentosu 2002 yılının Şubat ayında, Azerbaycan ile ilgili hazırlanan raporu kabul etti. Bu raporla $\mathrm{AB}$ 'nin Azerbaycan stratejisi; güvenlik, ekonomik ve siyasi başlıklar altında toplandı. Güvenlik başlığı altında Dağlık Karabağ'daki çatışma, uyuşturucu trafiği, mülteci sorunu gibi tehditlerle bunların çözümü üzerinde duruldu. Ekonomik ve siyasi başlıklar altında ise Azerbaycan'ın sahip olduğu petrol ve doğalgaz gibi enerji kaynaklarına AB'nin duyduğu ihtiyaç ve bunların işlenerek alternatif güzergâhlarla Avrupa pazarına ulaştırılmasındaki önem belirtilerek (Avrupa Parlamentosu Önergesi, 2002, 27 Mart) AB'nin RF'ye olan enerji bağımlılığının azalabileceği vurgulandı. Ayrıca bu raporla komşuları olan RF, İran ve Türkiye'ye Azerbaycan'daki gelişmelere katkı sağlamaları için tavsiyede bulunuldu (Özdağ, 2002: 65). 
2003 y1lının Haziran ayında yapılan Selanik Zirvesi’nde Azerbaycan Avrupa Komşuluk Politikası'na dâhil edilmedi. Fakat hemen ardından AB Konseyi, Azerbaycan politikasının da aktif olarak sürdürülebilmesi amaciyla Kafkasya'ya özel temsilci atanmasına karar vererek Finlandiyalı diplomat Heikiki Talvitie'yi görevlendirdi (Lynch, 2003: 186).

AB ile Azerbaycan ilişkilerinin önceliğini oluşturan ekonomik ve siyasi boyut gelişme gösterirken askerî boyut arka planda kalmıştır. Askerî ilişkilerin arka planda kalmasi; AB'nin, Azerbaycan ile ilgili politikasının ekonomik gerekçelere dayanmasının yanında askerî yapılanmasının da tamamlanmamış olmasından kaynaklanmaktadır. Bu bağlamda AB, Azerbaycan ile askerî ilişkiler geliştirememekte ve bu boyuttaki faaliyetlerini North Atlantic Organization (NATO) çerçevesinde yürütmektedir.

Benzer coğrafi kökenlere ve hemen hemen aynı üyelere sahip olmalarına rağmen, NATO ve AB savaş sonrası Avrupa'nın özel durumunda hedefleri, hukuki yapıları, görevleri, metotları ve yapısal kuruluşları açısından birbirlerinden çok farklı kuruluşlar olarak ortaya çıkmışlardır. Şu an NATO ve AB arasında bulunan anlaşma doğrultusunda bazı sınıflandırılmış dokümanlar paylaşılarak iki kurum da pratik konularda beraber çalışabilmektedirler. $\mathrm{AB}$ üyesi devletler, NATO çalışmalarının büyük çoğunluğuna aktif olarak katılmaktadırlar. Azerbaycan'daki AB politikasının askerî önceliklerini barış gücü, silahlarının sınırlandırılması, bilgi mübadelesi ve danışma hizmeti, ordu kuruculuğu, asayiş ve savunma ağırlıklı askerî eğitim, kadroların hazırlanması vb. çalışmalar oluşturmaktadır. $\mathrm{Bu}$ işbirliği mekanizmalarının başında Partnership for Peace (Barış İçin Ortaklık-BİO) gelmektedir (Robertson, 2001: 26).

\section{Avrupa Komşuluk Politikası}

Soğuk Savaş döneminde kurulan AB, Doğu Bloğu'nun dağılmasıyla kendini yenilemiş ve bütünleşmeye hız vermiştir. Güvenliğe yönelik tehdidin çeşitlendiği böyle bir ortamda AB, Komşuluk Politikası'nı devreye sokmuştur. AB'nin komşularıyla ilişkilerinin boyutunu farklılaştıran Avrupa Komşuluk Politikası, Belarus, Ukrayna, Moldova, Akdeniz ve Kafkas devletlerini kapsamıştır.

Son dönemde keşfedilen doğal kaynak rezervleri sayesinde uluslararası arenada önem kazanan Azerbaycan ile belli düzeyde ilişkilere sahip olan $A B$, Komşuluk Politikası ile Azerbaycan'da daha etkin bir şekilde var olma isteğini ortaya koymuştur. RF'nin Azerbaycan'1 arka bahçesi olarak görmesi ve ABD'nin Azerbaycan'a artan ilgisi ise AB'nin önündeki önemli engellerdendir.

AB'nin ortaya koyduğu Avrupa Komşuluk Politikası, Azerbaycan'a da yeni kapılar açmıştır. Kafkasya için özel bir temsilcinin atanmasıyla AB'nin Azerbaycan'daki çıkarları sebebiyle beklentisinin ve bu devlete ilgisinin de arttığ söylenebilir.

Gürcistan'da gerçekleşen Kadife Devrim, AB'nin genel olarak Kafkasya'ya ve özel olarak da Azerbaycan'a bakış açısını etkilemiştir. Bundan önce Azerbaycan'ın Avrupa Komşuluk Politikası'na dâhil edilmesi için Türkiye'nin üyeliğinin beklenmesi gerektiğini belirten $\mathrm{AB}$ yetkilileri, 2004 yılındaki genişlemeden sonra ise AB'nin Azerbaycan'da beklemeksizin kuracağı bir etkinliğin kendi yaşamsal çıkarlarıyla ilgili 
olduğunu belirtmişlerdir (Coppieters, t.y.). Buna göre AB'nin Azerbaycan'da iki hedefi vardır. Bunlar (Lynch, 2003: 156-158):

İstikrar ve Güvenlik: Dağl1k Karabağ sorununun barışç1 yollarla çözümlenmesi, güvenlik ve istikrarın tesis edilmesi için Azerbaycan'ın ekonomik olarak kalkındırılmasına destek olunmalıdır.

Kalkınma ve Refah Düzeyi: Azerbaycan'ın sahip olduğu enerji kaynaklarından dolayı gelişme potansiyeli yüksektir. Ayrıca bulunduğu coğrafi konum da bu devleti jeopolitik olarak önemli kılmaktadır. Azerbaycan'ın bu olanağını kalkınma ve refah yolunda kullanabilmesi için Dağlık Karabağ sorununu çözmesi ve Ermenistan'la karşılıklı diyalog geliştirmesi gerekmiştir.

$\mathrm{AB}$, Azerbaycan'daki hedeflerini hayata geçirebilmek için üç yol izlemiştir. Bunlar:

Hukukun Üstünlügü: $\mathrm{Bu}$ prensibin Azerbaycan'da uygulanmasıyla devletin hukuki yapısının tesis edilebileceği ve çatışmaların barışçıl yöntemlerle çözümlenebileceği belirtilmiştir. Hukukun üstünlüğünün sağlanması toplum ile devlet ilişkileri, insan hak ve özgürlükleri ile organize suçlarla mücadelede kaydedilecek gelişmenin en önemli koşullarındandır. Böylece yatırımcılar için Azerbaycan güvenli duruma gelirken $\mathrm{AB}$ sermayesinin de bu devlete nüfuzu için gerekli koşullar oluşabilecektir (Lynch, 2003: 159).

Cok Taraflllı Politikası: AB, Azerbaycan açısından çok taraflılık politikasının geliştirilmesi ve bu bağlamda Dağlık Karabağ sorununun da barışç1 yollarla çözümlenmesi için uluslararası aktörlerin rol almasını istemiştir. Bu nedenle AB, Azerbaycan'ın demokratik devletler, Birleşmiş Milletler (BM), Avrupa Güvenlik ve İşbirliği Teşkilatı (AGIT) ve Avrupa Konseyi (AK) ile ilişkilerinin geliştirilerek işbirliğine dönüştürülmesine destek vermiştir (Özen, 2004: 14).

Tutarlılık: AB'nin Azerbaycan'a uyguladığ 1 programlarla kullandığ ekonomik enstrümanlar esnasında sergilediği tutum etkinlik ve istikrar ortamı açısından önemlidir. AB'nin bu tutumu Azerbaycan tarafindan da olumlu karşılanmıştır (Lynch, 2003: 159).

AB'nin Komşuluk Politikası'ndaki temel amac1, Azerbaycan'1 siyasi ve ekonomik yörüngesinde tutmaktı. AB, EMPI Programı ile yaptığı yardımları belli koşullar altında vererek Azerbaycan'a AB perspektifi kazandırmayı ve AB'nin Azerbaycan'daki çıkarlarını koruma altına almayı hedeflemekteydi.

AB, Komşuluk Politikası ile Azerbaycan'a kısa ve orta vadede üyelik sözü vermemekte, kısa ve orta vadede üyeliğin Türkiye ve Balkan devletleri için mümkün olduğunu belirtmekteydi. EMPI Programı ile yapılan yardımlar ve ticari imtiyazlar, Azerbaycan'ın demokrasisinin gelişmesi ve serbest pazar ekonomisine yönlendirilmesi için kullanılan unsurlar olarak görülmekteydi.

AB, Azerbaycan'ın Komşuluk Politikası çerçevesinde tek pazarla entegre olmasını amaçlamasına rağmen hassasiyet gösterdiği bazı konular vardı. Bunlardan biri hizmetlerin serbest dolaşımıydı. Bu dolaşım için gerekli olan Schengen vizesi gelecekte Gürcistan ve Ukrayna'ya verilebilecek iken terörizm ve mülteci sorunları gibi nedenlerle Azerbaycan için geçerli olmayacağı belirtildi. Buna rağmen tek pazarla entegrasyon süreci kapsamında Azerbaycan için vize 
kolaylığı sözü verildi. Ticari konularda belli standartları yakalaması beklenen Azerbaycan için bazı ayrıcalıklar verilmesi öngörüldü. AB'nin, tarımın dış rekabete açılmasındaki katı tutumu Azerbaycan için büyük bir sorun teşkil etti. Zira AB'nin bu tarım politikası, ekonomisi tarım ile petrol ve doğalgaz gibi enerji kaynaklarına dayanan Azerbaycan'ın kalkınması ve gelişmesinin önündeki önemli bir engeldi (Özen, 2004: 15).

Avrupa Komşuluk Politikası'nın önemli bir yönü, AB'nin kimlik tanımlamasına ilişkindi. $A B$, kendi sınırlarını coğrafi olarak değil, siyasi ve kültürel temellerle tanımladı. Bu noktada, AB'nin Azerbaycan'a yönelik açılımı siyasi bir karakter de taşıdı. Müslüman bir devlet olan Azerbaycan ile yakın ilişkiler kurulması ve özellikle Türkiye'nin AB'ye üyelik perspektifi, medeniyetler çatışmasını önlemek amacıyla son derece anlamlıydı.

\section{Doğu Ortaklığı Politikası}

Doğu Ortaklığı girişimi, 2008 yılının Mayıs ayında AB üyesi devletlerin Dışişleri Bakanları'nın Brüksel'deki görüşmesi esnasında Polonya ve İsveç tarafindan ileri sürüldü. Bu teşebbüs, Doğu Avrupa ve Kafkas devletleri olan Belarus, Moldova, Ukrayna, Azerbaycan, Ermenistan ve Gürcistan'1 kapsamıştır (http://eeas.europa.eu/archives/delegations/azerbaijan/eu_azerbaijan/political_rela tions/eastern_partner ship/index_en.htm, ET: 23.03.2018).

Doğu Ortaklığı girişimi üzerine 2008 yılının Aralık ayında AB Komisyonu, Konsey'e ve Parlamento'ya bir bilgi belgesi sundu. Bu belge, Doğu Ortaklığı'na ilişkin Komisyon'un tutumu ve önerilerini yansıtmış ve AB'nin Azerbaycan, Gürcistan, Ermenistan, Belarus, Ukrayna ve Moldova ile işbirliği sürecinin genel çizgilerini belirlemiştir. 2009 yılının Mayıs ayındaki Prag Zirvesi'nde ise Doğu Ortaklığı girişiminin amaçlarını, ilkelerini ve işbirliği sürecinin genel çizgilerini belirleyen ortak bildiri kabul edilmiş ve Doğu Ortaklığı Politikası resmen başlamıştır (http://europa.eu/, ET: 18.03.2018).

AB, 2009'dan itibaren Doğu Ortaklı̆̆ı Politikası'nı uygulayarak Azerbaycan ile ilişkilerin daha üst düzeye çıkarılmasını ve Azerbaycan'la işbirliğinin devam ettirilerek geliştirilmesini öngörmüştür. $B u$ bağlamda $A B$ ve Azerbaycan arasında daha yoğun ilişkilerin oluşturulması amacıyla Ortaklık ve İşbirliği Anlaşması'nın yerine yeni bir anlaşmanın imzalanması, ikili arasında kapsamlı bir serbest ticaret bölgesinin oluşturulması, Azerbaycan enerjisinin $\mathrm{AB}$ pazarına taşınması ve enerji güvenliğinin sağlanması amacıyla daha derin işbirliğinin gerçekleştirilmesi planlanmıştır (http://eeas.europa.eu/archives/delegations/azerbaijan/eu_azerbaijan/ political_relations/eastern_partnership/index_en.htm, ET: 23:03.2018).

Doğu Ortaklığı Politikası, AB ve Azerbaycan arasındaki ilişkilere yeni bir boyut kazandırmıştır. $\mathrm{Bu}$ bağlamda $\mathrm{AB}$ ve Azerbaycan arasındaki ilişkilerde işbirliğini teşvik eden reformlar hakkında bilgi ve deneyim paylaşımı için dışişleri bakanları seviyesinde yılda bir toplantı yapılması öngörülmüştür. $A B$ ve Azerbaycan arasındaki ilişkilerde işbirliğinin temel alanlarına göre de dört platform oluşturulmuştur. Bunlar: Demokrasi, iyi yönetim ve istikrar; ekonomik bütünleşme ve $\mathrm{AB}$ politikalarına yakınlaşma; enerji güvenliği; $\mathrm{AB}$ üyesi devletlerin vatandaşları ile Azerbaycan vatandaşları arasında ilişkiler 
kurulmasıdır. Ayrıca Doğu Ortaklığı Politikası ile Azerbaycan'ın ve bu politikaya dâhil olan diğer devletlerin liderleriyle iki yılda bir zirve yapılması tasarlanmıştır (http://mfa.gov.az/?options=content\&id=566, ET: 25.03.2018). Bütün bunlarla birlikte Doğu Ortaklığı Politikası'nın hayata geçirilmesi için temel finansal araç olan ENI Programı, AB tarafından 2014'ten itibaren devreye sokulmuştur.

\section{Avrupa Komşuluk ve Doğu Ortaklığı Politikaları'nın Küresel ve Bölgesel Aktörler Bağlamında Değerlendirilmesi}

AB'nin Azerbaycan'da etkin olma çabaları hem küresel hem de bölgesel güçlerin politikalarını yeniden değerlendirmelerine sebep olmuştur. Özellikle Azerbaycan'ı arka bahçesi olarak gören ve bütün politikalarını kendi güvenliğini sağlamak amaciyla geliştiren RF, AB'nin Azerbaycan'1 Avrupa Komşuluk ve Doğu Ortaklığı Politikaları'na dâhil etmesini tehdit olarak algılamıştır (İvanov, 2012: 118). Bu bağlamda RF, AB'nin bu politikalarının kendisini etkinlik kaybına uğratacağını düşünerek $A B$ 'nin Azerbaycan'da güç kazanmasını istememiştir.

ABD'nin, McKinder'in teorisinden hareketle 11 Eylül'den sonra Azerbaycan'a olan ilgisi artmıştır. Yüzyılın Anlaşması ile Amerikan petrol şirketleri Azerbaycan'a girmiş ve bu durum Amerikan yönetiminin Azerbaycan'a ilgisinin artmasına neden olmuştu. Bu bağlamda ABD'nin Azerbaycan'a yönelik tutumunda enerji faktörü ve Azerbaycan'ın jeostratejik konumu belirleyici etkenlerdendir. $A B$ 'nin oluşum sürecine de destek veren $\mathrm{ABD}, \mathrm{AB}$ 'nin Azerbaycan'a uyguladığ 1 Avrupa Komşuluk ve Doğu Ortaklığı Politikaları'nı olumlu karşılamıştır. Çünkü her iki tarafın da amacı, Azerbaycan'daki RF'nin etkisini sınırlamak, güvenlik ve istikrarı sağlamak ve Azerbaycan'ı dünya ekonomisiyle bütünleştirmektir.

Türkiye, AB'nin uyguladığı Avrupa Komşuluk ve Doğu Ortaklığı Politikaları'nın başarısı için önemli bir aktördür. Türkiye'nin Azerbaycan ile iyi ilişkileri vardır. Türkiye'nin AB'ye üyelik perspektifi, Azerbaycan tarafindan da desteklenmiştir. Müslüman, demokratik ve laik bir devlet olan Türkiye'nin tam üyeliği için sürecin devam etmesi, Azerbaycan'ın AB'ye bakış açısını olumlu yönde etkilemiştir.

Azerbaycan'ın AB'ye bakış açısı, Avrupa Komşuluk ve Doğu Ortaklığı Politikaları'nın başarıya ulaşmasında en önemli faktördür. Azerbaycan, AB'yi Batı tarzı ilerlemenin sembolü olarak görmüştür. Bu bakış açısının gelişiminde, RF'nin Azerbaycan'a ilişkin politikaları etkili olmuştur. Bağımsızlığını kazandıktan sonra RF baskısını yoğun bir şekilde hisseden Azerbaycan'da AB çıkış kapıs1 olarak görülmüştür. $\mathrm{Bu}$ bağlamda Azerbaycan, $\mathrm{AB}$ ve üyesi devletlerle ilişkilerini geliştirerek işbirliğine dönüştürmeye çalışmıştır.

\section{SONUÇ}

İkinci Dünya Savaşı'na kadar dünya sisteminin merkezinde bulunan Avrupa, 1945'ten sonra Bat1 ve Doğu Bloğu olmak üzere iki bloğa bölündü. Bu dönemde Avrupa siyasetini belirleyici faktör, Soğuk Savaş döneminde SB'ye karşı ABD'nin yanında yer almaktı.

Soğuk Savaş'ın sona ermesi, iki Almanya'nın birleşmesi ve Varşova Paktı'nın dağılmasının hemen ardından o döneme kadar Batı Bloğu'nda ABD'nin yanında siyasetini sürdüren $\mathrm{AB}$, özellikle Maastricht Antlaşması'nın imzalanmasından sonra 
bağımsız bir ses ve güç alanı hâline geldi. $\mathrm{Bu}$ doğrultuda $\mathrm{AB}$, kendine özgü politikalar geliştirmeye başladı.

1990'lardan itibaren AB, jeostratejik olarak çok önemli olan Azerbaycan için yeni bir politika belirleme gereksinimi duydu. AB, temelde Avrupa'daki bütün devletleri aynı çatı altında topladıktan sonra komşu durumuna gelecek olan Azerbaycan ile iyi ilişkiler geliştirmeyi hedefledi.

$\mathrm{AB}$, SB dağıldıktan sonraki ilk yıllarda Azerbaycan stratejisini belirlemekte geç kalmasına rağmen ilerleyen dönemde petrol ve doğalgaz gibi enerji kaynakları, eski İpek Yolu'nu yeniden canlandırma, Avrupa Komşuluk ve Doğu Ortaklığı gibi politikalar çerçevesinde Azerbaycan'1 ekonomik olarak destekleyerek yakınlaşma sürecine girmiştir. 1996 yılında imzalanan Ortaklık ve İşbirliği Anlaşmasıyla da ikili ilişkilerin hukuki temelleri atılmıştır.

İç ve diş güvenliği tesis etmeyi öncelikli politika olarak benimseyen $A B$, Soğuk Savaş'tan sonra yaşanan çatışmaları durdurmak için 1995 yılında Madrid'de yapılan zirvede Avrupa'nın siyasi gündemini belirledi. Böylece genelde eski SB devletleriyle, özelde de Azerbaycan ile iyi ilişkiler kurularak Avrupa için bir güvenlik sistemi oluşturulması öngörüldü. 2003 yılındaki Selanik Zirvesi'nde oluşturulan Avrupa Komşuluk Politikası ve 2009'da uygulamaya konulan Doğu Ortaklığı Politikası, AB'nin Azerbaycan ile işbirliği geliştirmesini ve $A B$ 'de güvenlik sisteminin kurulmasını sağlamaya çalışmıştır.

Azerbaycan ise AB'nin ekonomik, sosyal, kültürel alandaki politikalarına ve güvenlik stratejisine kendi geleceği ve güvenliği açısından büyük önem vermiştir. $\mathrm{Bu}$ bağlamda Azerbaycan, $\mathrm{AB}$ ile ilişkilerin geliştirilmesi ve işbirliği sürecine girilmesi için AB'ye yönelik politikalarını genişletmeye çalışmıştır.

2009'dan itibaren on yıldır uygulanan Doğu Ortaklığı Politikası çerçevesinde $\mathrm{AB}$, bu politikaya dâhil olan diğer devletlerle yaşanan sorunların bir benzerini Azerbaycan'la yaşamıştır. AB'ye üyelik perspektifi sunulmadığı durumlarda devletlerdeki siyasal, demokratik ve ekonomik reformların sağlanmasında ve $\mathrm{AB}$ standartlarına yükseltilmesinde istenen sonuç elde edilememiştir. Bu şartlar altında AB'nin, en azından enerji güvenliği de dâhil güvenlik stratejisini ilgilendiren Azerbaycan ile ilişkilerinde etkili olabilmesinin tek yolu Dağlık Karabağ sorununun barışçıl yollarla çözümlenmesinde daha aktif bir rol üstlenmesidir. Bununla birlikte Azerbaycan'ın da beklentisi; AB'nin, Doğu Ortaklığı Politikası çerçevesinde Azerbaycan ile ilişkilerini geliştirmesi ve Dağlık Karabağ sorununun çözümünde arabuluculuk rolünü oynamasıdır.

Dağlık Karabağ sorunu, AB'nin Azerbaycan ile ilişkilerinde ve ekonomik işbirliğinin önünde engel teşkil etmiştir. $\mathrm{AB}$, Azerbaycan'in toprak bütünlüğünü desteklemiş, fakat bu destek de son derece sınırlı kalmıştır. Bunun en büyük nedeni, Dağlık Karabağ sorununun barışçıl yollarla çözümü konusunda çalışmalar yapan AGIT Minsk Grubu'nda AB değil de üyeleri Fransa, Almanya, İtalya, Portekiz, Hollanda, İsveç ve Finlandiya'nın yer almalarıdır. Azerbaycan'ın toprak bütünlüğünü destekleyen AB'nin, Dağlık Karabağ sorununda somut adımlar atabilmesinin temel çözüm mekanizması ise AGİT Minsk Grubu'nda aktif yer almasıyla gerçekleşebilir. $\mathrm{Bu}$ bağlamda $\mathrm{AB}$, üye devletlerinin kendi ulusal politikalarını AB'nin çıkarlarının 
üstünde tutmaları yüzünden Dağlık Karabağ sorununun barışçıl yollarla çözümü konusunda hareket edemez durumda olduğu söylenebilir. Dolayısıyla AB'nin diş politikada etkili olabilmesinin yolu, kendi iç sorunlarını çözüme kavuşturabilmesinden geçmektedir. Yani AB'nin, Avrupa Komşuluk ve Doğu Ortaklığı Politikaları kapsamında ne kadar politika üretirse üretsin, Dağlık Karabağ sorununun çözümünde başarılı olamadığı sürece Azerbaycan ile ilişkilerin her yönüyle geliştirilemeyeceği ve bu devlette etkin olamayacağı söylenebilir.

Genel olarak değerlendirildiğinde Azerbaycan ile $\mathrm{AB}$ arasındaki ilişkilerin dört farklı çerçevede oluştuğu söylenebilir. Bunlar; eski Sovyet coğrafyasındaki devletlerden biri olarak kurulan ilişkiler, bölgesel boyutta oluşturulan ilişkiler, $\mathrm{AB}$ ve üye devletlerle geliştirilen ikili ilişkiler ve uluslararası örgütler çerçevesindeki ilişkilerdir.

$\mathrm{AB}$, dış politikasını oluştururken bazen belli bir coğrafyayı, bazen de siyasi ya da dinî kriterleri dikkate alarak hareket eder. Akdeniz coğrafyası, Balkanlar, eski Sovyet devletleri gibi. Böylece AB, bazı kategorilerle devletlere özellik katarak bu devletler arasında ortak çıkar ya da bağ kurmayı amaçlamıştır. Genelde eski SB devletleriyle özelde ise Azerbaycan ile imzalanan Ortaklık ve İşbirliği Anlaşması ve yine bu devletlere yönelik oluşturulan TACIS Programı, AB'nin bu çerçevede kurduğu ilişkilerdendir. AB'nin Azerbaycan ile bölgesel boyutta oluşturduğu ilişkilere ise TRACECA, INOGATE, ENPI ve ENI programları ile Avrupa Komşuluk ve Doğu Ortaklığı politikaları örnek olarak gösterilebilir.

$A B$ ve üyesi devletler de Azerbaycan ile ikili ilişkiler geliştirmiştir. $A B$ kurum olarak çeşitli nedenlerle Azerbaycan'la ilişki kurmuştur. Örneğin AB, Azerbaycan'da Dağlık Karabağ çatışmasından sonra bir milyonun üzerinde mülteciye yardım etmiştir. $\mathrm{AB}$ üyesi devletler kendi başlarına da Azerbaycan'la ikili ilişkiler geliştirmişlerdir. İngiltere, Fransa, Almanya ve İtalya'nın Azerbaycan'la yakın ilişkileri oluşmuştur.

$\mathrm{AB}$, Azerbaycan ile uluslararası örgütler çerçevesinde de yoğun ilişkiler içine girmiştir. İlişkilerdeki bu yoğunluk, Azerbaycan'da yaşanan etnik ve ekonomik kriz ve Ermenistan ile aralarındaki sınır anlaşmazlığından kaynaklanmaktadır. Dağlık Karabağ sorunu nedeniyle Azerbaycan da Ermenistan da AGiT ile yoğun ilişki içine girmiştir. AB üyesi devletlerin ve RF’nin de üye olduğu AGíT, Dağlık Karabağ sorunu ile ilgili çalışmalar yapmıştır. Bu sorunun barışçıl yollarla çözümlenmesine yönelik olarak AGITT bünyesinde Minsk Grubu oluşturulmuştur. Ayrıca Azerbaycan, AK'ye de üyedir. Demokratik değerler, insan hak ve özgürlükleri gibi konularda Azerbaycan, AK içinde AB üyesi olan devletlerle yakın iliş̧i içinde bulunmaktadır.

\section{KAYNAKÇA}

Arat, Tuğrul Ve Çağrı Erhan; (2001), “Aet'yle İlişkiler”, İç. Baskın Oran (Ed.), Türk Dış Politikası; Kurtuluş Savaşından Bugüne Olgular, Belgeler, Yorumlar, İstanbul: İletişim Yayınları, Ss. 807-853.

Avrupa Komisyonu; (1998, 3 Temmuz), "Programma Tacıs, Godovoy Otçet Za 1997 God (Tacıs Programı, 1997 Yılı Raporu)", Ss. 4-13.

Avrupa Komisyonu; (1999, 7 June), "The European Union's Relations With The South Caucasus, Under The Partnership And Cooperation Agreements", 272 Final, Ss. 2-8.

Avrupa Parlamentosu Önergesi; (2002), "Eu Relations With South Caucasus", İnternet Adresi: Http://Www.Europarl.Eu/MeetDocs/Delegations/Caus/20020327/Gahrton\%20resolutionen\%2

0 En.Pdf, Erişim Tarihi: 28.03.2018. 
Baykal, Sanem; (2003), “Avrupa Birliği’nin Kurumsal Yapısı”, Basılmamış Ders Notu, Ankara: Ankara Üniversitesi Hukuk Fakültesi.

Çernyavskiy, S.; (1998), "Zapadnaya Aktivnost Vı Zakavkaze”, Mejdunarodnaya Jizn, 6, Ss. 11-17.

Coppieters, Bruno; (T.Y.), "An Eu Special Representative To Azerbaijan New Periphery", İnternet Adresi: Http://Www.İss-Eu.Org, Erişim Tarihi: 21.03.2018.

Dartan, Muzaffer Ve Esra Hatipoğlu; (2001), “Avrupa Birliği Genişleme Sürecinin Karadeniz Ekonomik İşbirliği Bölgesine Etkileri”, Marmara Avrupa Araştırmaları Dergisi, 2, Ss. 8192.

Davutoğlu, Ahmet; (T.Y.), “Türkiye-Ab İlişkisinin Stratejik Boyutu”, Yeni Türkiye Dergisi, 1(1), Ss. 491-512.

Davutoğlu, Ahmet; (2001), Stratejik Derinlik, İstanbul: Küre Yayınları.

Demir, Ali Faik; (2003), “Ab'nin Güney Kafkasya Politikası”, İç. Beril Dedeoğiu (Ed.), Dünden Bugüne Avrupa Birliği, İstanbul: Boyut Matbaacılık, Ss. 365-380.

Fairbanks, Charles; (2003), “Kafkasya'da Ve Orta Asya'da Puça Çıxan Ümidler”, I11. Sektor, 3, Ss. 2-9.

Hasanov, Ali; (1998), Azerbaycan'ın Xarici Siyaseti: Avropa Dövletleri Ve Abş (1991-1996), Bakü: Dövlet Neşriyyatı.

Heqq, Müşfiq; (1997, 7 Mart), “Avropa Birliği Ve Azerbaycan”, Qanun, S. 7.

İvanov, İgor; (2012), Novaya Rossiyskaya Diplamatiya, Moskova: Olma Press.

Http://Economy.Gov.Az/İndex.Php?Option=Com_Content\&View=Article\&İd=1038\&Itemid=183\& Lang=Az, Erişim Tarihi: 16.03.2018.

Http://Europa.Eu/, Erişim Tarihi: 18.03.2018.

Http://Ec.Europa.Eu/External_Relations/Ceeca/Tacis/İndex.Htm, Erişim Tarihi: 05.01.2018.

Http://Eeas.Europa.Eu/Archives/Delegations/Azerbaijan/Eu_Azerbaijan/Political_Relations/Eastern _Partnership/ İndex_En.Htm, Erişim Tarihi: 23.03.2018.

Http://Eeas.Europa.Eu/Archives/Docs/Enp/Pdf/Pdf/Country/Enpi_Nip_Azerbaijan_En.Pdf, Erişim Tarihi: 17.03.2018.

Http://Eur-Lex.Europa.Eu/Legal-Content/En/All/?Uri=Celex:21999a0917\%2801％29， Erişim Tarihi: 12.03.2018.

Http://Mfa.Gov.Az/?Options=Content\&İd=566, Erişim Tarihi: 25.03.2018.

Https://Www.Avrupa.İnfo.Tr/Tr/News/Ab-Azerbaycan-İliskileri-4431, Erişim Tarihi: 16.03.2018.

Https://Www.Avrupa.İnfo.Tr/Tr/News/Ab-Azerbaycan-İliskileri-8942, Erişim Tarihi: 15.03.2018.

Http://Www.Enp1-İnfo.Eu/Library/Content/Azerbaijan-National-İndicative-Programme-2011-2013, Erişim Tarihi: 02.03.2018.

Http://Www.Enp1-İnfo.Eu/Main.Php?İd=402\&İd_Type=2\&Lang_İd=450, $\quad$ Erişim $\quad$ Tarihi: 12.03.2018.

Https://Www.Euneighbours.Eu/Library/Content/Azerbaijan-National-İndicative-Programme-20112013, Erişim Tarihi: 16.02.2016.

Http://Www.İnogate.Org/, Erişim Tarihi: 18.01.2018.

Https://Www.Stat.Gov.Az/, Erişim Tarihi: 17.03.2018.

Hüseynova, Hicran; (2016, 23 Ekim), “Avropa'ya Entegrasiya”, Azerbaycan Gazetesi, S. 2.

İtar-Tass Haber Ajansı; (2018, 14 Mart), İnternet Adresi: Http://Www.Tass.Ru, Erişim Tarihi: 14.03.2018.

Komıssına, Irina; (2001), "Perspektivi İntegratsii Respublik Zakafkazya V1 Evropeyskiy Soyuz", İnternet Adresi: Http://Www.Ca-C.Org/Online/2001/Journal_Rus/Cac01/10.Komisr.Shtml, Erişim Tarihi: 19.07.2009.

Lobjakas, Ahto; (2014), "Eu: European Commission Unveils Details Of Neighbourhood Strategy", İnternet Adresi: Http://Www.Rferl.Org/Featurearticleprint/2014/05/077d3a66-3883-4119972e-Cc470a9f, Erişim Tarihi: 16.12.2014.

Lorot, Paskal Ve François Thual; (2001), Goepolitika, Çev.: Fuad Hesenoğlu, Bakü: Azerbaycan Neşriyyat1.

Lynch, Dov; (2003), "The Eu: Towards A Strategy", The South Caucasus: A Challenge Fort The Eu, Paris: Institute For Security Studies European Union, Ss. 155-198. 
Pescatore, Pierre; (1987), "Some Critical Remarks On The Single European Act", Common Market Law Review, 24, Ss. 9-18.

Marquina, Antonio; (2000), "Foreign And Security Policy Of The European Union Towards The Caucasus", İn Antonio Marquina Ve Hans Gunter (Ed.), Political Stability And Energy Cooperation İn The Mediterranian, Berlin: Afes Press, Ss. 221-232.

Özdağ, Ümit; (2002), Türkiye-Avrupa Birliği İlişkileri (Jeopolitik İnceleme), Ankara: Asam Yayınları. Özen, Suat; (2004), “Avrupa Birliği’nin "Yeni Komşuluk Politikası” Bağlamında Güney Kafkasya”, Avrasya Stratejik Araştırmalar Merkezi, Ankara: Asam Yayınları, Ss. 1-23.

Robertson, Lord George; (2001), "Turkey And The European Security And Defence Identity", Insight Turkey, 3 (1), Ss. 21-36.

Sander, Oral; (1998), Siyasi Tarih (1918-1994), Yedinci Bask1, Ankara: İmge Kitapevi.

Töre, Nahit; (1996), Avrupa Birliği Ve Türk Cumhuriyetleri, İstanbul: Friedrich Ebert Vakfi.

\section{SUMMARY}

The end of the Cold War and the collapse of the Soviet Union caused the two-pole world system to change profoundly. In this period, the European Union, which was leaving its static structure and adopting a dynamic structure, has started to develop its relations with Azerbaijan, which has rich natural resources and strategic importance. The European Union firstly provided financial assistance to Azerbaijan under the title of Technical Assistance to the Commonwealth of Independent States Program, and then increased its assistance by implementing the energy policy with the policy of restoring the historic Silk Road. The purpose of these policies implemented by the European Union is to guarantee transportation security by increasing the energy supply alternatives. On the other hand, the purpose of Azerbaijan, which benefits from this assistance, is to protect its independence and to ensure regional cooperation. The European Union has diversified its economic assistance to Azerbaijan within the framework of European Neighbourhood and Partnership Instrument and European Neighbourhood Instrument Programs since 2007. In general the European Union has implemented financial support to Azerbaijan and the parties have become closer to each other. The legal basis of this rapprochement between the European Union and Azerbaijan was laid with the ratification and entry into force of the Partnership and Cooperation Agreement.

These steps taken by the European Union for integration have brought about some problems. The enlargement of the European Union towards the Central and Eastern European states has brought about problems especially with security. In this context, the European Union has included this state in the European Neighbourhood Policy in 2004 and the Eastern Partnership Policy in 2009 in order to prevent the threats coming from Azerbaijan. Azerbaijan has given great importance to the economic assistance and security policy of the European Union in terms of its own future and security. In this context, Azerbaijan has deepened by expanding its policies towards the European Union in order to develop relations with the European Union and to enter into a process of rapprochement.

The purpose of this study is to examine the economic relations developed by the policies which are activating the energy and historic Silk Road again and the Technical Assistance to Commonwealth of Independent States, European Neighbourhood and Partnership Instrument, European Neighbourhood Instrument 
Programs; the legal relations laid down by the Partnership and Cooperation Agreement and the political relations framed by the European Neighbourhood and Eastern Partnership Policies. In conclusion above all, the European Union and Azerbaijan have assumed the responsibility of globalization rather than a regional integration and they have successfully progressed in their aim until today. 